\title{
Problem Based Learning to Increase Activity and Learning Outcomes of Students Primary School
}

\author{
Sofijah, Muhari, Suhanadji \\ Universitas Negeri Surabaya \\ Surabaya, Indonesia \\ sofijah2@gmail.com
}

\begin{abstract}
This classroom action research aims to improve the activity and learning outcomes through the application of problem-based learning model. This research is a classroom action research using design from Kemmis Taggart covering 4 stages: (1) planning, (2) action, (3) observation, and (4) reflection. The subjects in this research were 32 elementary school students. This research was conducted in 3 cycles. The results of the study included (1) the activity of students in the first cycle reached 70, the second cycle reached 75, and the third cycle reached 87.5 (2) the learning outcomes in the cycle I completed 47, student learning mastery reaches 75 , and cycle III student learning mastery reach 90.62. Therefore, it can be concluded that the implementation of problem-based learning model can improve the activity and learning outcomes of students of the primary school.
\end{abstract}

Keywords-Problem Based Learning, activity, learning outcomes.

\section{INTRODUCTION}

Education is one of the most important sectors that has a direct contribution to the quality of human resources [1]. The quality of human resources is aimed at achieving national excellence in national development.

In the 2014 school's academic year, the government has set all schools both primary and secondary schools should implement the 2013 Curriculum. The 2013 curriculum is prepared to produce productive, creative, innovative, and character human resources. For those purposes, educators must be able to prepare learners with various abilities that are learning to know, learning to do, learning to live together, learning to be, and learning to Faith and Taqwa [2].

One of the subthemes that should be understood by the students of class $\mathrm{V}$ is the economic role in the efforts of prospering people's lives. To understand the economic role in efforts to improve the lives of people in elementary school students is not easy. Many issues are related to social problems that occur in the community. To solve the problem, it requires solution by involving the role of student activity in both physical and thought activity [3].

Previously the researcher has conducted observations at SDN Dr. Sutomo I. Learning that has been done in SDN Dr. Sutomo I found that there are some obstacles in the field, namely still many students who have not mastered the material and the low interest of students in studying the material so the effect is low value of students (below limits).

The teachers have tried to overcome the problems and obstacles. These efforts are changing the learning strategies and methods.

The learning model prioritized in the implementation of the 2013 curriculum is the learning model of project-based learning, problem-based learning, inquiry [2] it is a change of learning paradigm, which focuses on students and trained to develop communication skills, working together, and problems solving, so the learning outcomes are increasing.

Related to the description of the activity and the result of the learning condition of class V SDN. Dr. Sutomo I / 323 Surabaya which is still categorized lack, hence on the action research will use the model of problem-based learning to increase activity and student learning outcomes.

Arends [4] states that the problem-based learning model is a learning where children become the center of attention in learning to solve problems in real-world situations.

Nur [5] argues that there are three theoretical and empirical support in the problem-based learning model, such as:

a) Dewey and problem-oriented classes

Dewey's view that schools are a place for problem-solving research authentically. Dewey's pedagogical perspectives encourage educators to engage learners in problem-oriented activities. The orientation of the problem is closely related to the problem-based learning model. These problems must be solved by the learners to find a solution.

b) Piaget, Vygotsky, and constructivism.

A constructivist learning theory that requires learners to investigate their environment by building a personal knowledge of the lessons learned. Piaget's learning theory of cognitive processes integrates a stimulus that can be either perceptions, concepts, laws, principles or new experiences into the schema that already exists in a person's mind. Vygotsky's theory of learning places an important role in the social 
aspects of learning. Vygotsky believes social relationships with others drive on building new ideas and enriching intellectuals for learners. These three theories emphasize the cognitive processes required in the problem-based learning model.

c) Bruner and discovery learning.

Discovery learning emphasizes active experiences and learners centered on learners. Through learning activities, the learners find their own ideas and gain meaning. When discovery learning is applied in social science, it emphasizes the characteristics of inductive reasoning and inquiry processes of scientific methods.

Based on several supporting theories that have been described, the problem-based learning model applied to the subtheme of economic activity strongly supports learners to think to solve problems.

Through learning on the subthemes of economic activity using problem-based learning has the advantage for learners to grow critical and skilled thinking that is developing the cognitive thinking of learners so that they are able to build meaningful concepts through the gathering of facts. Learners learn with a number of problems and dealing with certain situations that are contextual. Learners also learn in groups, build harmony in the divergence of each dynamic member, and make systematic observations or investigations [1].

This problem-based learning model is appropriate to be an alternative problem-solving in improving activity and students learning outcomes because:

(1) The model of learning problem-based learning is a model that is preferred in the implementation of the 2013 curriculum [2].

(2) The using of problem-based learning as an instructional strategy to improve student performance that is cognitive and non-cognitive [6].

(3) The problem-based learning model is a model of constructivist that is oriented on student-centered learning that is able to improve creativity, collaborative, thinking metacognition, developing high-level thinking skills, increasing independence, facilitating problem-solving, and building teamwork [7].

Based on the above description, then in an effort to improve the activity and learning outcomes of students of class V primary school, the researcher conducted a class action research entitled The Application of Problem Based Learning Model to Improve Student Activities and Learning Outcomes of Primary School.

\section{RESEARCH METHODS}

The research design used in this research is Classroom Action Research[8]. The variable of the cause (independent variable) in this research is the problem-based learning model. The result variable (dependent variable) in this research is activity and student learning outcomes. The subject of this class action research is all V SDN students. Dr. Sutomo I / 323 Surabaya in the academic year 2017/2018, with the number of 32 students, who consist of 20 male students and 12 female students. The research design used in this research is Kemmis and Mc Taggart model with the repetitive cycle. Each cycle consists of four components, namely a) planning; b) acting; c) observing; and d) reflection.

Data collection techniques used in this study are observations and tests. Observations are used to determine student learning activities, observe the results of affective learning and psychomotor students. The test is used to measure the cognitive learning outcomes of subthemes of economic activity. Evaluation of learning outcomes is done at the end of each cycle.

The instrument in this research consists of student activity sheet, observation sheet of student affective learning outcomes, and observation sheet of student psychomotor learning outcomes. After obtained the data of further research is analyzed by quantitative descriptive technique.

\section{RESULTS AND DISCUSSION}

\section{A. Preparation of Learning}

Based on the validation results that have been done by the validator I who is an expert of education and learning expert whereas the validator II is a material expert. Validation is done on instructional devices and research instruments. The result of learning device validation and research instrument for Lesson Plan (LP) is 3.33, BAPD is 3.43; LKPD is 3.5; test of learning outcome that is 3.5 and student activity that is 3.45 it shows that the average of assessment of both validators is in the good category. This means that the LP, BAPD, LKPD, a test of learning outcomes, and student activities can be used with a bit of revision. Revisions are made based on suggestions from validators.

\section{B. The Implementation of Learning.}

The implementation of the learning process of economic activity subtheme by using problem-based learning model in the first cycle of students tend to be passive, because students do not understand the learning model used by the teacher, and the students do not dare to express their opinions and to ask the teachers about the learning materials that are difficult to understand. As a result, in cycle I, the success indicator of student activity and learning outcomes has not been exceeded.

The revision is made in cycle II at the beginning of learning. The teacher explains first about the learning stages of the problem-based learning model.

Teachers often invite students to ask questions, provide opportunities to ask questions and express opinions and provide guidance and motivate at every stage of learning activities. This is in accordance with his opinion [9] the teacher should give encouragement in the ongoing learning process. 
The Implementation of learning cycle II, the teacher has implemented the problem-based learning model well, and the characteristics of problem-based learning have been implemented. In group discussion activities many students propose or respond to problems. To overcome the problems teachers should provide opportunities for students who rarely ask or respond to problems. In cycle II activity and student learning outcomes still not exceeded the indicator of success.

In cycle III the shortcomings that exist in cycle II can be solved so it can increase student activity and learning outcomes because it has exceeded the indicators of the success of learning.

\section{Student Activities}

Based on observations made by two observers in learning by implementing problem-based learning model, students' activity in cycle I-III shows that in the 1 st cycle the success obtained $70 \%$, it has not increased. In $2^{\text {nd }}$ cycle obtained a success $75 \%$, and it also has not increased yet because it has not exceeded the success indicator where the indicator of the success of at least $80 \%$, and on 3rd cycle obtained a success $87.5 \%$. In the third cycle, the observation of student activity has improved because it exceeds the predetermined success indicator. The indicator of success that has been set at least $80 \%$ of students active in learning. It can see the results of student activity improvement as follow

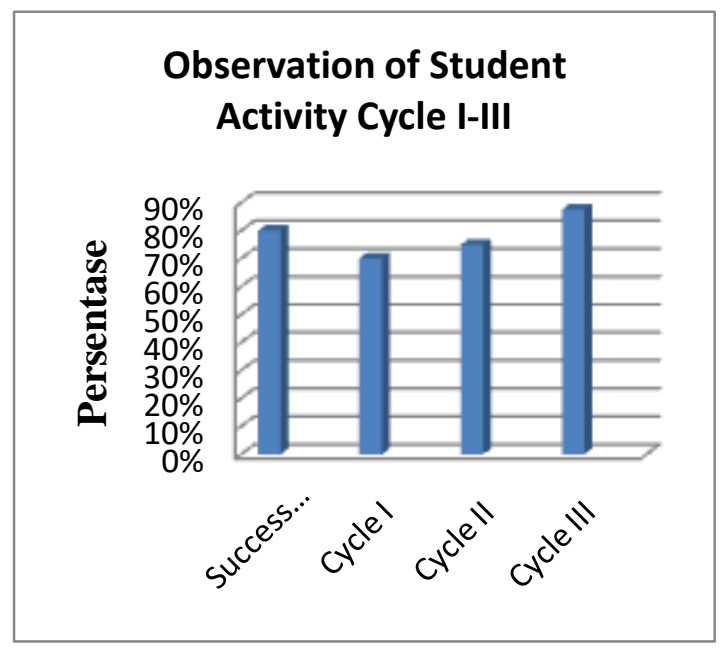

Observation of Student Activity Cycle I-III

\section{Student Learning Results}

\section{Cognitive Learning Outcomes}

The completeness of classical learning in cycle I after applying the learning with problem-based learning model $47 \%$ obtained of learning mastery, while the average student learning outcomes of 71.93. Based on indicators of the success of learning, the 1st cycle can be said that it hasn't increased yet, because it has not reached the indicator of classical success in learning at least $80 \%$ of students reach. Learning outcomes or individual minimal pass criteria, it is considered passed when they reach 75 . In the second cycle student learning outcomes in a classical gain $75 \%$. While the average student learning outcomes are 75.31. The 2nd Cycle can be said has not increased, because it has not reached the indicator of success in learning.

In the third cycle, student learning outcomes are $90.62 \%$. While the average student learning outcome is 77.81. By reaching of classical completeness of $90.62 \%$, it means that in the 3rd cycle has increased that is set a minimum $80 \%$. Student cognitive learning outcomes can be seen in the graph below.

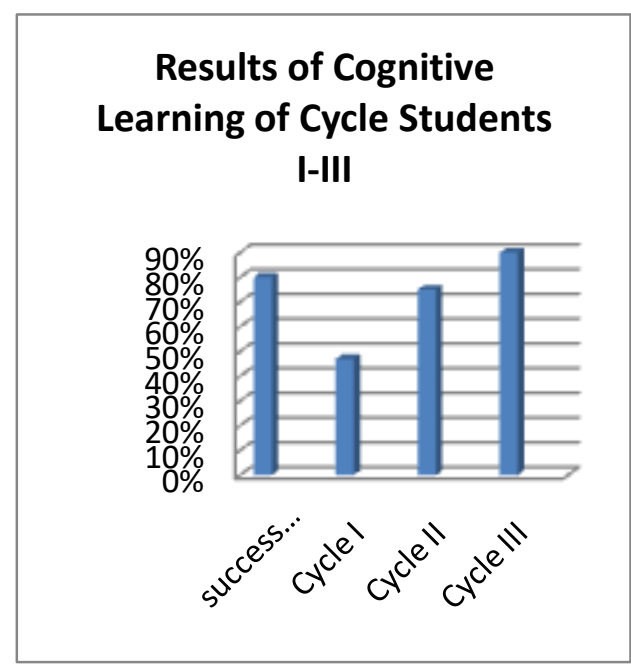

Graph 2. Results of Cognitive Learning of Cycle Students I-III

\section{Affective Learning Outcomes}

Students' affective learning outcomes that include collaborative skills or group discussions, paying attention to classroom discussions or when the teacher is explained, and dare to express an opinion or answer questions. The result of affective learning from cycle I-II has not shown improvement yet, because it has not achieved success indicator of $80 \%$. In the first cycle students who are good at learning outcomes reached 18 students or $56.25 \%$. While the ones who are not good is 14 students or $43.75 \%$. In the second cycle students who are good at learning outcomes reached 25 students or $78.12 \%$. While that is not good is 7 students or $21.87 \%$. Moreover, in the third cycle of affective learning, there are 28 good students or $87.5 \%$, while the rest of $12.5 \%$ or 4 students are not good. This means that in cycle III, there is a minimum of $80 \%$ improvement in the learning outcomes. The result of affective learning of cycle I-III can be seen from the graph below. 


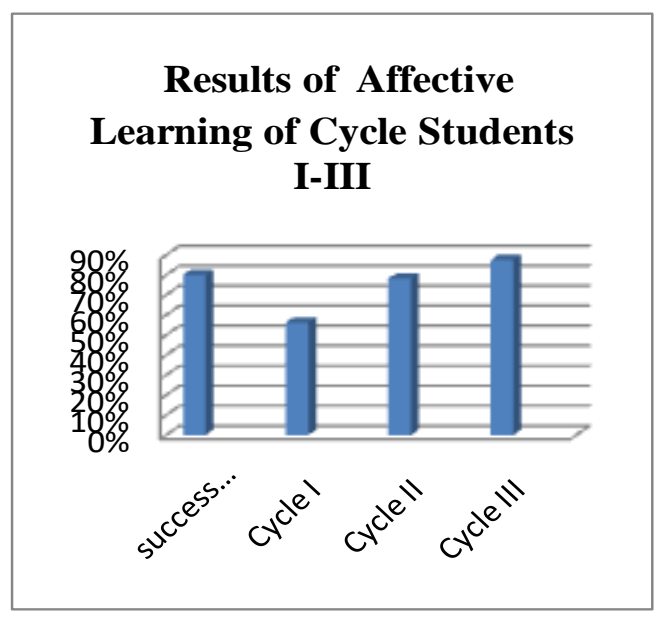

Graph 3. Results of Affective Learning of Cycle Students I-III

\section{Psychomotor Learning Outcomes}

Psychomotor student learning outcomes that include the ability of the accuracy of work steps, work activities, and task report completeness. Psychomotor learning outcomes from cycle I-II have not shown improvement, because it has not achieved the success indicator of learning by $80 \%$. In the first cycle, students who have good results in learning include 20 students or $62.5 \%$. While the ones who are not good involve 12 students or $37.5 \%$. In the second cycle students who are good at learning outcomes reached 27 students or $84.37 \%$ while not good is 5 students or $15.62 \%$. And on the third cycle of psychomotor learning outcomes for good students is 29 students or $90.62 \%$, for students who have not good is 3 students or $9.38 \%$. This means that in cycle III, there is a minimum of $80 \%$ improvement in the learning outcomes. The result of affective learning of cycle I-III can be seen from the picture below.

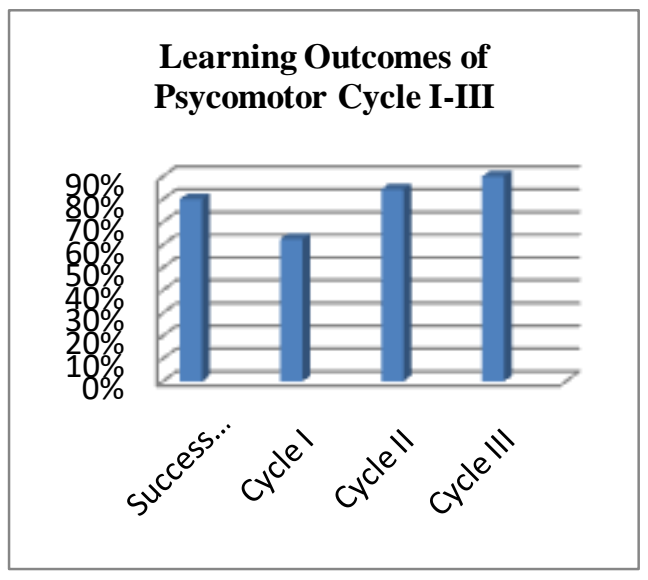

Graph 4. Learning Outcomes of Psychomotor Cycle I-III

Based on the results of the above analysis we can generally conclude that the application of problem-based learning model has been successful in improving the quality of learning. This is marked by students happy to follow the learning process, student learning activities are increased, student-centered learning activities and the implementation of problem-based learning has also been successful in improving cognitive, affective, and psychomotor learning outcomes. This success proves that the problem-based learning model can actually be applied in elementary school level.

Improving the quality of learning after application of problem-based learning model in class $\mathrm{V}$ primary school is very reasonable, because if it is studied in depth during the research process that the application of problem-based learning model are: (1) Contextual because the problem used in learning is a real problem in daily life. (2) Constructivist because it gives students the opportunity to build their own knowledge from experience in learning. (3) Cooperative because it gives students opportunities to interact and cooperate with friends to solve the problems[10].

\section{CONCLUSIONS AND SUGGESTIONS}

This research conclude that the application of problem-based learning model with the subject of economic activity on learning social studies in class $\mathrm{V}$ primary school can improve student learning activities. Moreover, the application of problem-based learning model with a subtheme of economic activity in class $\mathrm{V}$ primary school can improve cognitive, affective, and psychomotor learning outcomes. Some suggestions that the researchers can point out include: 1) the application of problem-based learning model can be used to improve student activity and learning outcomes especially on subtema of economic activity and 2) the application of problem-based learning model can also be used for other learning alternatives.

\section{REFERENCES}

[1] S. Ahmad, "Pengembangan Pembelajaran IPS di Sekolah Dasar." Jakarta, 2014

[2] E. Mulyasa, "Guru dalam implementasi kurikulum 2013," Bandung PT Remaja Rosdakarya Offset, 2014.

[3] Sardiman, Interaksi dan motivasi Belajar Mengajar. Jakarta: PT. Raja Gravindo Persada, 2012.

[4] R. I. Arends, Teaching for Student Learning. New York: Routledge, 2010 .

[5] M. Nur, "Model pembelajaran berdasarkan masalah," Surabaya Pus. Sains dan Mat. Sekol. UNESA, 2011.

[6] A. O. Fatade, D. Mogari, and A. A. Arigbabu, "Effect of Problem-Based Learning on Senior Secondary School Students' Achievements in Further Mathematics.," Acta Didact. Napocensia, vol. 6, no. 3, pp. 2744, 2013.

[7] H. Sofyan and K. Komariah, "Pembelajaran problem based learning dalam implementasi kurikulum 2013 Di SMK," J. Pendidik. Vokasi, vol. 6, no. 3, pp. 260-271, 2016.

[8] E. T. Stringer, Action research in education. Pearson Prentice Hall Upper Saddle River, NJ, 2008.

[9] A. W. Gunawan, “Genius learning strategy," Jakarta: Gramedia pustaka utama, 2003.

[10] H. Rachma, Pengembangan Profesi Guruan IPS. Bandung: Alfabeta, 2014 . 